\title{
EVALUATION OF THE STOCKS OF Hypnea musciformis (RHODOPHYTA: GIGARTINALES) ON TWO BEACHES IN BAHIA, BRAZIL
}

Taira Aguiar Caires ${ }^{1,2^{*}}$, Iara Oliveira Costa ${ }^{2,3}$, Priscila Barreto de Jesus ${ }^{1,2}$, Mara Rojane Barros de Matos ${ }^{4}$, Guilherme Henrique Pereira-Filho ${ }^{5}$ and José Marcos de Castro Nunes 2, 3, $^{2}$

${ }^{1}$ Universidade Estadual de Feira de Santana (PPGBot - UEFS) - Departamento de Ciências Biológicas Programa de Pós Graduação em Botânica

(Av. Universitária, s/n. 44031-460, Feira de Santana, Bahia, Brasil)

${ }^{2}$ Universidade Federal da Bahia - Instituto de Biologia

Departamento de Botânica, Laboratório de Algas Marinhas (LAMAR)

(Campus de Ondina, 40210-730 Salvador, BA, Brasil)

${ }^{3}$ Universidade do Estado da Bahia - Programa de Pós-Graduação em Biodiversidade Vegetal (PPGBVeg) (Rua Silveira Martins, 2555, 41150-000 Salvador, BA, Brasil)

${ }^{4}$ Universidade do Estado da Bahia - Departamento de Ciências Exatas e da Terra (Campus II, Alagoinhas, BA, Brasil)

${ }^{5}$ Universidade Federal Rural do Rio de Janeiro - Departamento de Botânica (Caixa Postal 74582, 23851-970 Seropédica, RJ, Brasil)

*Corresponding author: taiaracaires@ yahoo.com.br

\section{A B S T R A C T}

Hypnea musciformis occurs widely in the northeast coast of Brazil, and it is one of the most important natural sources of k-carrageenan, which is used in food and cosmetic industries. Despite its potential for exploitation little is known about its ecology. The aim of this study was to investigate the biology and ecology of $H$. musciformis in Brazil through analyses of biomass stock and accompanying flora. Two populations of $\mathrm{H}$. musciformis were analyzed: those on the beaches of Stella Maris and Itacimirim (Bahia, Brazil). Eight samplings were conducted between 2007 and 2009 during the dry and rainy seasons. The algae were sampled along transects $(20 \mathrm{~m})$ using quadrats $(0.04$ $\mathrm{m}^{2}$ ) in three different hydrodynamic regions of the reefs (TP, PRR and FRR). The t-Test, Dunn's Test and parametric and nonparametric ANOVA were used for statistical analyses. 17 host species and 41 associated species were identified. The highest biomass stock was observed during the dry season. On Stella Maris, the region with the highest biomass stock was FRR; on Itacimirim, TP had the highest biomass value. This study permits the assumption that seasonality, microhabitat, hydrodynamic and micro scale factors contribute to variation in biomass stock in $\mathrm{H}$. musciformis populations.

\section{RESUMO}

Hypnea musciformis ocorre amplamente na costa nordeste do Brasil, sendo uma das mais importantes fontes naturais de k-carrageenana que é utilizado nas indústrias alimentícia e cosmética. Apesar do potencial de explotação, pouco se sabe sobre sua ecologia. O objetivo deste estudo foi conhecer a biologia e ecologia de $H$. musciformis no Brasil através da análise do estoque de biomassa e da flora acompanhante. Duas populações de H. musciformis foram analisadas nas praias de Stella Maris e Itacimirim (Bahia, Brasil). Oito amostragens foram realizadas entre 2007 e 2009, durante as estações seca e chuvosa. As algas foram coletadas ao longo de transectos $(20 \mathrm{~m})$ utilizando quadrados $(0,04$ $\mathrm{m}^{2}$ ) em três diferentes regiões hidrodinâmicas dos recifes (TP, PRR e FRR). t-Test, Teste de Dunn e ANOVA paramétrica e não-paramétrica foram utilizados para a análise estatística. Foram identificadas 17 espécies hospedeiras e 41 espécies associadas. O maior estoque de biomassa foi observado durante a estação seca. Em Stella Maris, a região com maior estoque de biomassa foi FRR, e em Itacimirim, TP apresentou biomassa maior. Este estudo permite supor que sazonalidade, microhabitats, hidrodinamismo e fatores em microescala contribuem para a variação no estoque de biomassa em populações de $H$. musciformis.

Descriptors: Bahia, Biomass, Carragenophyte, Seasonal Variation, Seaweed.

Descritores: Bahia, Biomassa, Carragenófita, Variação Sazonal, Alga. 


\section{INTRODUCTION}

The species Hypnea musciformis (Wulfen in Jacquin) J.V. Lamour is widespread along the coast of Bahia. This seaweed is one of the natural sources of the polysaccharide $k$-carrageenan, which is widely used in the food, cosmetics and textile industries as a thickener. The pharmaceutical industry also uses kcarrageenan for its antiviral and anti-inflammatory properties, as well as a vermifuge and muscle relaxant (SCHENKMAN, 1989; REIS; YONESHIGUEVALENTIN, 1998; BRAVIN; YONESHIGUEVALENTIN, 2002). According to Lourenço and Marques Jr. (2009), due to H. musciformis' economic importance, natural populations of the species have suffered indiscriminate harvesting, especially in northeastern Brazil.

Hypnea musciformis can develop on a variety of substrata and can be epiphytic or grow floating (GUIST JR et al., 1982). Schenkman (1989) reported the species Sargassaum cymosum C. Agardh as the main host of $\mathrm{H}$. musciformis, and also registered as important substrata the red algae Laurencia scoparia J. Agardh, Bryothamnion seaforthii (Turner) Kuetzing and Acanthophora spicifera (Vahl) Boergesen. Also, Reis and Yoneshigue-Valentin (1998) observed the genus Sargassum C. Agardh as $H$. musciformis' main host.

Some countries have undertaken studies to evaluate the variation in the development of natural populations of Hypnea musciformis. For instance, Rao (1970), in a study conducted in India, indicated a rapid increase in stocks of $H$. musciformis in November, with peak of dry biomass from December to February. Guist Jr et al. (1982) observed that the natural stocks of $H$. musciformis in Florida, USA, were higher when solar radiation was minimal and that, from June to September, there were no populations at all at the collection sites. Both studies observed the peak of biomass during the winter. Friedlander and Zelikovitch (1984) studied natural populations in Israel and observed that the growth season was from April to December (from spring to summer), being positively correlated to temperature and light intensity. Aziza et al. (2008) conducted a study in Morocco and found that natural populations showed periods of active growth from May to November (from spring to late autumn).

Despite the intense exploitation of Hypnea musciformis, few ecological studies have been carried on the coast of Brazil for the purpose of recording the spatial-temporal variation in natural populations of this species. Of the few studies conducted one may quote those of Schenkman (1989) and Faccini and Berchez (2000) in São Paulo, Reis and YoneshigueValentin (1998) in Rio de Janeiro, and Wallner et al. (1992) in Bahia.
The assessment of biomass stocks found in these studies has shown that populations of Hypnea musciformis vary depending on seasonality and certain environmental factors, such as water temperature, low diurnal tides, hydrodynamics and herbivory (SCHENKMAN, 1989; WALLNER et al., 1992; REIS; YONESHIGUE-VALENTIN, 1998; FACCINI; BERCHEZ, 2000). According to Reis and Yoneshigue-Valentin (1998), the same environmental factor can interfere differently in the growth of $H$. musciformis depending on the collection site, evidencing the variation in the stocks of this species over time and space.

This study contributes to the knowledge of the biology and ecology of $H$. musciformis through analyses of its biomass stock, as well as of its accompanying flora.

\section{Material and Methods}

Study Sites

Two epiphyte populations of Hypnea musciformis were analyzed in the state of Bahia, on the beaches of Stella Maris $\left(12^{\circ} 56^{\prime} 22^{\prime \prime} \mathrm{S}, 38^{\circ} 19^{\prime} 41^{\prime \prime W}\right)$ and Itacimirim $\left(12^{\circ} 36^{\prime} 53^{\prime \prime} \mathrm{S}, 38^{\circ} 02^{\prime} 31^{\prime \prime} \mathrm{W}\right)$, located in Salvador and Camaçari, respectively (Fig. 1).

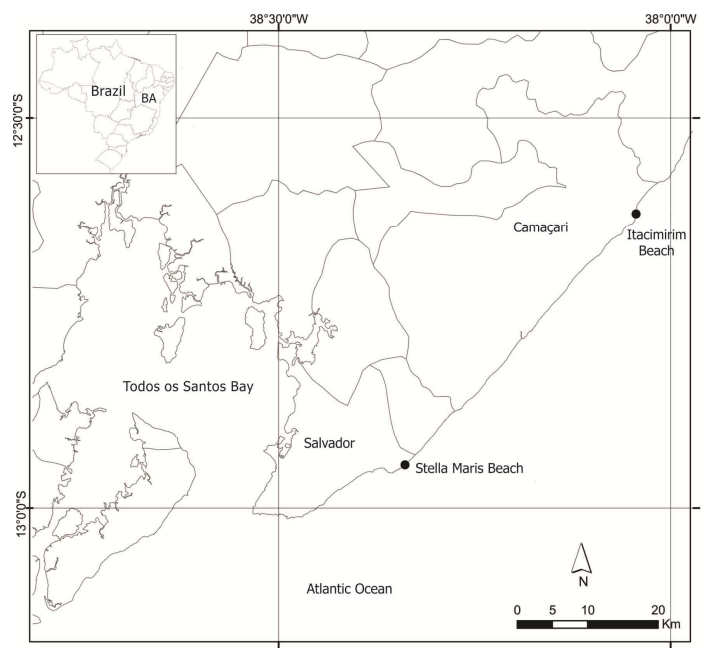

Fig. 1. Map showing the localization of the study area: Stella Maris (Salvador) and Itacimirim (Camaçari), Bahia, Brazil.

At Stella Maris beach the reef consists of Precambrian metamorphic basement and Quaternary beachrock with calcareous crust. At Itacimirim beach the reef consists of carbonate rock, mainly populated by coral and coralline encrusting algae (LEÃO, 1996).

The climate in the coastal region of Bahia ranges from humid to sub-humid, with an average annual rainfall of $1500 \mathrm{~mm}$ and 200 days of sunshine/year. Air temperatures vary between 14 and $33^{\circ} \mathrm{C}$, and sea water temperatures from $20-27^{\circ} \mathrm{C}$ 
(MAIDA; FERREIRA, 1997). The rainy season in this region lasts from March to August, the dry season from September to February. Data on air and water temperature, sunlight, humidity and rainfall were provided by the National Institute of Meteorology (INMET).

\section{Field Samplings}

Eight samplings were taken between August 2007 and July 2009, 4 during the rainy season and 4 during the dry season. Samples were collected from the intertidal zone during low tides. The reefs were divided into microhabitats on the basis of their hydrodynamics, in accordance with Nunes and Paula (2002). The microhabitats were as follows: a Tidal Pools (TP) region, which presented varying depths, shapes and sizes, a Protected Reef Region (PRR), that emerged during low tide and was protected from direct wave action, and a Front Reef Region (FRR), a region of higher hydrodynamics, subject to direct wave action.

The sampling was performed using a destructive methodology. Three transects $(20 \mathrm{~m})$ were arranged parallel to the coastline in each microhabitat. Five points were marked at random on each transect, at each of which $0.04 \mathrm{~m}^{2}$ quadrat plots were sampled, all the specimens inside the plots being collected with a spatula. The algae collected were fixed in $4 \%$ formalin and later screened and identified in the laboratory using the techniques suggested by Nunes (2010). For the taxonomic arrangement of species, Wynne (2011) has been adopted.

To determine biomass, algae were dried at $60^{\circ} \mathrm{C}$ for $72 \mathrm{~h}$ until they maintained constant weight as recorded by means of a semi-analytical balance. The values of dry biomass are presented as a mean \pm standard deviation in grams per square meter $\left(\mathrm{gm}^{-2}\right)$.

\section{Statistical Analyses}

The Kolmogorov and Smirnov test was used to test the normality of the observed distribution. Variances were tested for homogeneity with Bartlett's test. Data which did not pass the test of normality were submitted to nonparametric ANOVA associating the Kruskal-Wallis test and Dunn's Multiple Comparisons (ZAR, 1999). The $t$-Test was used to verify the existence of significant differences in the biomass between beaches and the different periods sampled. One-Way Analysis of Variance (ANOVA) was used to verify the existence of significant differences in the biomass among microhabitats. The data were logtransformed and the confidence level for all tests of significance was set at $95 \%(p=0.05)$. For comparison of multiple means the Tukey-Kramer test (parametric) was applied. Analyses were performed with GraphPad Software for Windows version 3.06 (2003).

\section{Results}

Host and Associated Flora

The two populations of Hypnea musciformis analyzed presented epiphytic habits, occurring on 17 host species, representing the divisions Chlorophyta, Rhodophyta and Heterokontophyta. These epiphyte populations were more frequently observed growing on species of the division Rhodophyta, especially of the family Rhodomelaceae, represented by six taxa. The division Heterokontophyta presented four host species, among them Sargassum cymosum var. cymosum C. Agardh showed the greatest number of epiphytic Hypnea musciformis. The division Chlorophyta showed only one host species, Ulva lactuca L. Of the taxa studied, six were found exclusively on Stella Maris, two on Itacimirim and eight were common to both beaches (Table 1).

Table 1. Host species of Hypnea musciformis on the beaches of Stella Maris (Salvador) and Itacimirim (Camaçari), Bahia, Brazil. $(\mathrm{x})=$ present; $(-)=$ absent

\begin{tabular}{|c|c|c|c|c|}
\hline \multirow[t]{2}{*}{ Division } & \multirow[t]{2}{*}{ Family } & \multirow[t]{2}{*}{ Taxon } & \multicolumn{2}{|c|}{ Beaches } \\
\hline & & & Itacimirim & Stella Maris \\
\hline Chlorophyta & Ulvaceae & Ulva lactuca $\mathrm{L}$. & $\mathrm{x}$ & - \\
\hline \multirow[t]{4}{*}{ Heterokontophyta } & Dictyotaceae & Dictyopteris delicatula Lamour. & $\mathrm{x}$ & $\mathrm{x}$ \\
\hline & & Padina gymnospora (Kütz.) Sond. & $\mathrm{x}$ & $\mathrm{x}$ \\
\hline & Sargassaceae & Sargassum cymosum var. cymosum C. Agardh & $\mathrm{x}$ & $\mathrm{x}$ \\
\hline & Scytosiphonaceae & Rosenvingea sanctae-crucis Börgesen & $\mathrm{x}$ & - \\
\hline \multirow[t]{11}{*}{ Rhodophyta } & Corallinaceae & Amphiroa anastomosans Weber Bosse & $\mathrm{x}$ & $\mathrm{x}$ \\
\hline & & Jania capillacea Harv. & - & $\mathrm{x}$ \\
\hline & Gelidiellaceae & Gelidiella acerosa (Forssk.) Feldmann \& Hamel & $\mathrm{x}$ & $\mathrm{x}$ \\
\hline & Gracilariaceae & Gracilaria cervicornis (Turner) J. Agardh & $\mathrm{x}$ & $\mathrm{x}$ \\
\hline & Halymeniaceae & Cryptonemia seminervis (C. Agardh) J. Agardh & - & $\mathrm{x}$ \\
\hline & Rhodomelaceae & Acanthophora muscoides (L.) Bory & - & $\mathrm{x}$ \\
\hline & & Bryothamnion seaforthii (Turner) Kütz. & - & $\mathrm{x}$ \\
\hline & & Bryothamnion triquetrum (S.G. Gmel.)M. Howe & - & $\mathrm{x}$ \\
\hline & & Palisada perforata (Bory) K.W. Nam & $\mathrm{x}$ & $\mathrm{x}$ \\
\hline & & Digenea simplex (Wulfen) C. Agardh & $\mathrm{x}$ & $\mathrm{x}$ \\
\hline & & Vidalia obtusiloba (C. Agardh) J. Agardh & - & $\mathrm{x}$ \\
\hline \multicolumn{2}{|c|}{ Total species for beach } & & 10 & 14 \\
\hline
\end{tabular}


Hypnea musciformis was found epiphyting certain species in each microhabitat of the beaches of Stella Maris and Itacimirim, and species of Rhodophyta were the main substratum for Hypnea (Table 2).

Table 2. Host species of Hypnea musciformis more commonly occurring in each microhabitat of the beaches Stella Maris (Salvador) and Itacimirim (Camaçari), Bahia, Brazil

\begin{tabular}{lll}
\hline \hline Beaches/Microhabitats & Stella Maris & Itacimirim \\
\hline Tidal pool (TP) & $\begin{array}{l}\text { Gelidiella acerosa } \\
\text { Gelidiella acerosa }\end{array}$ & $\begin{array}{l}\text { Palisada perforata } \\
\text { Palisada perforata }\end{array}$ \\
$\begin{array}{l}\text { Protected reef region } \\
\text { (PRR) }\end{array}$ & $\begin{array}{l}\text { Bryothamnion } \\
\text { seaforthii }\end{array}$ & $\begin{array}{l}\text { Sargassum } \text { cymosum } \text { var. } \\
\text { cymosum }\end{array}$ \\
$\begin{array}{l}\text { Frontal reef region } \\
\text { (FRR) }\end{array}$ & & \\
\hline
\end{tabular}

The flora associated with Hypnea musciformis banks was represented by 41 species. The divisions Chlorophyta and Rhodophyta were the most commonly represented, with 18 and 16 species respectively. The division Heterokontophyta presented seven associated species.

\section{Environmental Variables}

The air temperature during the study period ranged from $23^{\circ} \mathrm{C}$ at its lowest to $27^{\circ} \mathrm{C}$ at its highest, with an average of $25.5^{\circ} \mathrm{C}$. There was a high rate of insolation during the sampling period, ranging from 8 to 10 hours per day. The humidity was high during the study period, ranging between 75 and $80 \%$, characteristic of the humid to subhumid climate of the coast of Bahia. The sea water had a minimum temperature of $23^{\circ} \mathrm{C}$, an average of $25.7^{\circ} \mathrm{C}$ and a maximum of $29^{\circ} \mathrm{C}$, typical values for this tropical region (INMET).

Table 3. Species of flora associated with Hypnea musciformis on the beaches Stella Maris (Salvador) and Itacimirim (Camaçari), Bahia, Brazil.

\begin{tabular}{|c|c|c|}
\hline Division & Family & Taxon \\
\hline \multirow[t]{17}{*}{ Chlorophyta } & Anadyomenaceae & Anadyomene stellata (Wulfen in Jacq.) C. Agardh \\
\hline & \multirow[t]{4}{*}{ Caulerpaceae } & Caulerpa cupressoides $(\mathrm{H}$. West in Vahl) C. Agardh \\
\hline & & C. mexicana Sond. exKütz. \\
\hline & & C. racemosa (Forsskal) J.Agardh \\
\hline & & C. sertularioides (S.G.Gmel.) M. Howe \\
\hline & \multirow[t]{2}{*}{ Codiaceae } & Codium taylorii P.C. Silva \\
\hline & & C. intertextum Collins \& Herv. \\
\hline & Cladophoraceae & $\begin{array}{l}\text { Cladophora prolifera (Roth) Kütz. } \\
\text { C. vagabunda (L.) C. Hoek }\end{array}$ \\
\hline & \multirow[t]{5}{*}{ Halimedaceae } & Halimeda cuneata $\mathrm{K}$. Hering \\
\hline & & H. discoidea Decne. \\
\hline & & H. gracilis Harv. ex J. Agardh \\
\hline & & H. incrassata (J. Ellis) J.V. Lamour. \\
\hline & & H. opuntia (L.) J.V. Lamour. \\
\hline & Siphonocladaceae & Dictyosphaeria verluysii Weber Bosse \\
\hline & \multirow[t]{2}{*}{ Ulvaceae } & Ulva fasciata Delile \\
\hline & & U. rigida $\mathrm{C}$. Agardh \\
\hline & Valoniaceae & Valonia aegagropila $\mathrm{C}$. Agardh \\
\hline \multirow[t]{7}{*}{ Heterokontophyta } & \multirow[t]{6}{*}{ Dictyotaceae } & Canistrocarpus cervicornis (Kütz.) De Paula \& De Clerck \\
\hline & & Dictyopteris justii J.V.Lamour. \\
\hline & & Dictyota jamaicensis W.R.Taylor \\
\hline & & Lobophora variegata (J.V.Lamour.) Womersley ex E.C. Oliveira \\
\hline & & Padina boergesenii Allender \& Kraft \\
\hline & & Spatoglossum schröederi (C. Agardh) Kütz. \\
\hline & Scytosiphonaceae & Colpomenia sinuosa (Roth) Derbès \& Solier \\
\hline \multirow[t]{16}{*}{ Rhodophyta } & \multirow[t]{2}{*}{ Corallinaceae } & Amphiroa fragilissima (L.) J.V.Lamour. \\
\hline & & Spyridia hypnoides (Bory in Belanger) Papenf. \\
\hline & Galaxauraceae & Dichotomaria marginata (J.Ellis \& Sol.) Lamarck. \\
\hline & Gigartinaceae & Chondracantus acicularis (Roth) Fredericq in Hommersand et al. \\
\hline & \multirow[t]{6}{*}{ Gracilariaceae } & Hydropuntia cornea (J. Agardh) M. J. Wynne \\
\hline & & H. caudata (J. Agardh) Gurgel \& Fredericq \\
\hline & & Gracilaria cuneata Aresch \\
\hline & & G. curtissae J. Agardh \\
\hline & & G. cylindrica Borgesen \\
\hline & & G. dominguensis (Kütz.) Sond. ex Dickie \\
\hline & Lomentariaceae & Gelidiopsis variabilis (grev. Ex J. Agardh) F. Schmitz \\
\hline & \multirow[t]{4}{*}{ Rhodomelaceae } & Acanthophora spicifera (Vahl) Börgensen \\
\hline & & Amansia multifida J.V.Lamour. \\
\hline & & Enantiocladia duperreyi (C. Agardh) Falkenb. \\
\hline & & Herposiphonia bipinnata $\mathrm{M}$. Howe \\
\hline & Solieriaceae & Solieria filiformis (Kütz.) P.W. Gabrielson \\
\hline
\end{tabular}


The average number of rainy days per month, as well as the average monthly rainfall accumulation, for the rainy and dry seasons, were calculated based on yearly precipitation data for 2007 , 2008 and 2009 (INMET). In the rainy season, there were monthly averages of about 15 days with rain and $285 \mathrm{~mm}$ of accumulated rainfall. For the dry season, the monthly average was 5.5 days with rain and $160 \mathrm{~mm}$ of accumulated rainfall. The fluctuation of these rates in the months of sampling is listed in Figure 2.

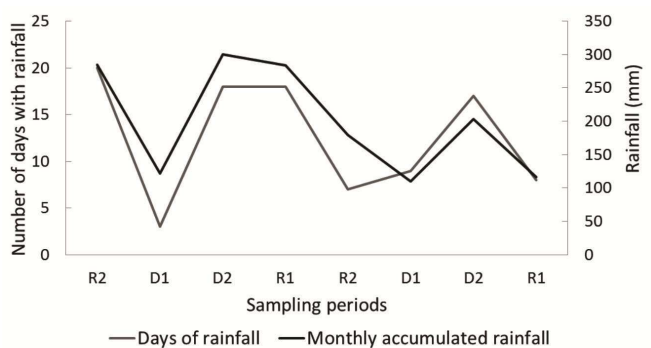

Fig. 2. Fluctuation in the number of days with rain and monthly accumulated rainfall in sampling periods to the beaches of Stella Maris (Salvador) and Itacimirim (Camaçari), Bahia, Brazil. R1 e R2: March and August (rainy season), respectively; D1 e D2: September and February (dry season), respectively.

\section{Dynamics of Biomass}

Hypnea musciformis occurred in the three microhabitats of the beaches of Stella Maris and Itacimirim throughout the sampling period. The biomass stock of the microhabitats of the two beaches showed no significant difference $(\mathrm{p}>0.05)$. However, analyses of each individual beach's microhabitats showed that they differ significantly. The analyses revealed significant differences $(p<0.005)$ between microhabitats on Stella Maris beach, where production was higher in the frontal reef region (FRR) and lower in the tide pool (TP). Itacimirim beach presented higher yields in the tide pool (TP) and lower ones in the protected region of the reef (PRR). The statistical analyses showed significant differences between microhabitats on this beach $(p<0.01)$ (Table 4).

Table 4. Representation of averages $( \pm$ SD) of dry biomass values $\left(\mathrm{gm}^{-2}\right)$ of Hypnea musciformis obtained in each microhabitat of the beaches of Stella Maris (Salvador) and Itacimirim (Camaçari), Bahia, Brazil.

\begin{tabular}{|c|c|c|c|c|}
\hline $\begin{array}{l}\text { Microhabitats/ } \\
\text { Beaches }\end{array}$ & $\begin{array}{l}\text { Tidal } \\
\text { pool } \\
\text { (TP) }\end{array}$ & $\begin{array}{l}\text { Protected } \\
\text { reef reg ion } \\
(\mathrm{PRR})\end{array}$ & $\begin{array}{l}\text { Frontal reef } \\
\text { region (FRR) }\end{array}$ & $\begin{array}{c}\text { Total } \\
\text { dry } \\
\text { biomass }\end{array}$ \\
\hline Stella Maris & $3.4 \pm 0.3$ & $4.2 \pm 0.3$ & $4.3 \pm 0.4$ & 11.9 \\
\hline Itacimirim & $6.5 \pm 0.7$ & $4.0 \pm 0.3$ & $5.8 \pm 0.4$ & 16.3 \\
\hline $\begin{array}{l}\text { Total dry } \\
\text { biomass }\end{array}$ & 9.9 & 8.2 & 10.1 & 28.2 \\
\hline
\end{tabular}

Regarding seasonality, biomass stock was higher in the dry season on both the beaches, with 7.9 $\pm 0.4 \mathrm{gm}^{-2}$ for Stella Maris, and $10.2 \pm 0.6 \mathrm{gm}^{-2}$ for Itacimirim, differing significantly from that of the rainy season $(\mathrm{p}<0.005)$, which attained a production of $4.0 \pm 0.3 \mathrm{gm}^{-2}$ for Stella Maris, and $6.0 \pm 0.3 \mathrm{gm}^{-2}$ for Itacimirim.

The influence of seasonality was evident in the biomass stock of the microhabitats. For Stella Maris, there were significant differences among all the microhabitats between the dry and the wet seasons. Itacimirim beach presented values that only differed significantly between all the microhabitats in the rainy season (Table 5).

Table 5. Representation of significant differences in biomass among microhabitats, depending on the seasonality of the beaches of Stella Maris (Salvador) and Itacimirim (Camaçari), Bahia, Brazil. R1 and R2: March and August (rainy season), respectively; D1 and D2: September and February (dry season), respectively; NS: no significant difference.

\begin{tabular}{|c|c|c|c|c|}
\hline $\begin{array}{l}\text { Sampling } \\
\text { periods/ } \\
\text { Beaches }\end{array}$ & R1 & R2 & D1 & D2 \\
\hline Stella Maris & $\begin{array}{l}\text { TP } \times \text { PRR } \\
(P<0.001) \\
P R R \times \text { FRR } \\
(P<0.05)\end{array}$ & $\begin{array}{l}\text { TP } \times \text { FRR } \\
(\mathrm{P}<0.01) \\
\mathrm{PRR} \times \mathrm{FRR} \\
(\mathrm{P}<0.05)\end{array}$ & $\begin{array}{l}\text { TP x FRR } \\
(\mathrm{P}<0.001)\end{array}$ & $\begin{array}{l}\text { TP x PRR } \\
(\mathrm{P}<0.001)\end{array}$ \\
\hline Itacimirim & $\begin{array}{l}\text { TP x PRR } \\
(P<0.05) \\
P R R \times \text { FRR } \\
(P<0.001)\end{array}$ & $\begin{array}{l}\text { TP x FRR } \\
(\mathrm{P}<0.001) \\
\mathrm{PRR} \times \text { FRR } \\
(\mathrm{P}<0.001)\end{array}$ & NS & NS \\
\hline
\end{tabular}

When all the sampling periods are considered, a variation in biomass stock between the first and the last month of each season may be seen. For Stella Maris beach, during the rainy season, there was a significant decrease in biomass stock in March (R1) and the population's recovery started in August (R2). During the dry season, biomass stock became constant, with the exception of that of the front reef region which presented a decrease in September (D1). The recovery began in February (D2), as may be observed in Figure 3.

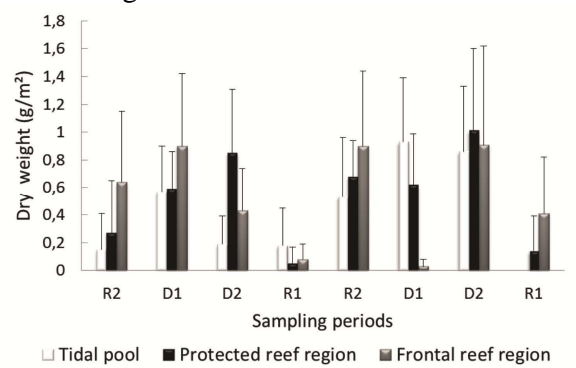

Fig. 3. Graphical representation of the mean ( \pm SD) biomass of Hypnea musciformis of microhabitats as a function of seasonality on the beach of Stella Maris (Salvador), Bahia, Brazil. R1 e R2: March and August (rainy season), respectively; D1 e D2: September and February (dry season), respectively. ( $\mathrm{n}=360$ samples). 
As for Itacimirim, no abrupt changes in biomass stock were observed during the study period, with the exception of the protected reef region (PRR) which showed a large decrease in March (R1) (Fig. 4).

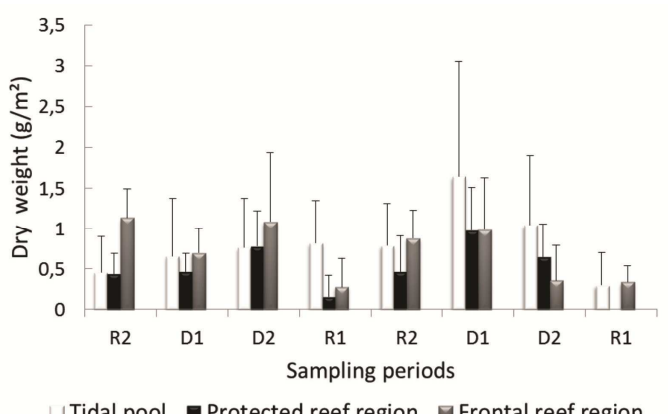

Fig. 4. Graphical representation of the mean ( \pm SD) biomass of Hypnea musciformis of microhabitats as a function of seasonality on the beach of Itacimirim (Camaçari), Bahia, Brazil. R1 e R2: March and August (rainy season), respectively; D1 e D2: September and February (dry season), respectively. ( $\mathrm{n}=360$ samples).

\section{DisCUSSION}

Previous studies undertaken on the coast of Bahia, such as those of Altamirano and Nunes (1997), Nunes (1998), Nunes et al. (1999), Nunes et al. (2001) and Lucio and Nunes (2002) reported a widespread occurrence of Hypnea musciformis in the three microhabitats analyzed in this study.

The protected reef (PRR) and tidal pool (TP) regions presented the rhodophytes as the main substratum for Hypnea musciformis. This relationship was also observed by Schenkman (1989) and Nunes et al. (2001). The frontal reef region (FRR) of Itacimirim presented the brown algae Sargassum as the main substratum, thus confirming this species as an important substratum available for natural populations of $H$. musciformis (OLIVEIRA; BERCHEZ, 1987; BERCHEZ et al., 1989; SCHENKMAN, 1989; BERCHEZ et al., 1993; REIS; YONESHIGUE-VALENTIN, 1998; FACCINI; BERCHEZ, 2000).

In relation to microhabitats, biomass stock on Stella Maris beach was higher in the front reef region (FRR), due to that region's characteristics. This region remains submerged even during low tides, thus avoiding the desiccation of the algal population (REIS et al., 2003, 2008).

The tidal pools (TP) contain many microenvironments, which may lead to greater variability in biomass production, as observed in this study. This microhabitat presented the lowest values of biomass on Stella Maris and the highest on
Itacimirim. In addition to the effect of the several microenvironments that occur in this microhabitat, the observed result may also have been influenced by solar radiation, as during low tides the pools are not subject to any movement of the water, possibly thus enhancing the penetration of sunlight (REIS; YONESHIGUE-VALENTIN, 1998).

The desiccation during daytime low tides which occurs in the protected reef region (PRR) may have had a direct influence on the low values of biomass presented by the Itacimirim beach. According to Reis and Yoneshigue-Valentin (1998), the populations in this region are most likely due to desiccation because of the period of emersion during low tides. The high relative humidity of the air $(80 \%)$ recorded during the period of the study may have prevented further reductions in biomass stock.

As for seasonality, Reis and YoneshigueValentin (1998) and Faccini and Berchez (2000) found no evident seasonal pattern in the biomass stock of Hypnea musciformis for the populations of Rio de Janeiro and São Paulo, contrary to the pattern found in this study, with higher biomass values occurring during the dry season (September to February). Rao (1970) and Guist Jr (1982) observed an increase in biomass stocks during the winter, while Friedlander and Zelikovitch (1984) and Aziza et al. (2008) reported the increase during the months from June to September, during the summer.

The analysis of the sampling periods showed that, during the rainy season, the total biomass decreased on both beaches in March (R1). This reduction is probably due to the high rate of rainfall recorded in this period in addition to the winds and daytime low tides, which may have caused the fragmentation of the thallus of the algae, thus reducing the stock of biomass (SCHENKMAN, 1989; REIS; YONESHIGUE-VALENTIN, 2000; WALLNER et al., 1992).

The dry season is characterized by lower rainfall. So it follows that the probability of the maintenance of the algal population is higher because the movement of water and the likelihood of fragmentation of the thallus are reduced. Probably, seasonality, the environment (microhabitats), the hydrodynamic and micro scale factors, together contribute to the increase or decrease of the biomass of Hypnea musciformis populations.

This context suggests that to facilitate the exploitation and rational management of populations of Hypnea musciformis, it is necessary to analyze the change in biomass of this seaweed at each of the sites of its potential use, taking into consideration the population's capacity for recovery, as the biomass of this species generally varies over time and space (REIS; YONESHIGUE-VALENTIN， 1998，2000; REIS et al., 2008). 


\section{ACKNOWLEDGEMENTS}

We wish to thank MSc. Goia Lyra for translating the manuscript and Brendan Lee for reviewing the English text.

\section{REFERENCES}

ALTAMIRANO, M.; NUNES, J. M. C. Contribuciones al macrofitobentos del municipio de Camaçari (Bahia, Brasil). Acta Bot. Malacitana, v. 22, p. 211-215, 1997.

AZIZA, M.; GIVERNAUD, T.; CHIKHAOUI-KHAY, M.; BENNASSER, L. Seasonal variation of the growth, chemical composition and carrageenan extracted from Hypnea musciformis (Wulfen) Lamouroux harvested along the Atlantic coast of Morocco. Sci. Res. Essay, v. 2, p. 509-514, 2008.

BERCHEZ, F. A. S.; PEREIRA, R. T. L.; MARQUES, H. L. A influência da predação na maricultura de Hypnea musciformis (Rhodophyta, Gigartinales). Ínsula, v.19, p. 71-82, 1989.

BERCHEZ, F. A. S.; PEREIRA, R. T. L.; KAMIYA, N. F. Culture of Hypnea musciformis (Rhodophyta, Gigartinales) on artificial substrates attached to linear ropes. Hydrobiologia, v. 260/261, p. 415-420, 1993.

BRAVIN, I. C.; YONESHIGUE-VALENTIN, Y. Influência de fatores ambientais sobre o crescimento in vitro de Hypnea musciformis (Wulfen) Lamouroux (Rhodophyta). Rev. Bras. Bot., v. 25, p. 469-474, 2002.

FACCINI, A. L.; BERCHEZ, F. Management of natural beds and standing stock evaluation of Hypnea musciformis (Gigartinales, Rhodophyta) in south-eastern Brazil. J. Appl. Phycol., v.12, p. 101-103, 2000.

GUIST Jr., G. G.; DAWES, C. J.; CASTLE, J. R. Mariculture of the red seaweed, Hypnea musciformis. Aquaculture, v. 28, p. 375-384, 1982.

FRIEDLANDER, M.; ZELIKOVITCH, N. Growth rates, phycocolloid yield and quality of the red seaweeds, Gracilaria sp., Pterocladia capillacea, Hypnea musciformis, and Hypnea cornuta, in field studies in Israel. Aquaculture, v. 40, p. 57-66, 1984.

LEÃO, Z. M. A. N. The coral reefs of Bahia: Morphology, distribution and major environmental impacts. An. Acad. Bras. Ciênc., v. 68, p. 439-452,1996.

LOURENÇO, S. O.; MARQUES JR, N. A. Produção primária marinha. In: Biologia marinha. 2 ed. Rio de Janeiro: Interciência, 2009. Cap. 6, p. 111-154.

LUCIO, A. M.; NUNES, J. M. C. Aportación al conocimiento fenológico de las rodofíceas marinas de la playa de Guarajuba (Camaçari, Bahia) Brasil. Bot. Complut.,v. 26, p. 17-34, 2002.

MAIDA, M.; FERREIRA, B. P. Coral reefs of Brazil: an overview. In: Internat. Coral Reef Symp., 8. v. 1, p. 263-274, 1997.

NUNES, J. M. C. Rodofíceas marinhas bentônicas da orla oceânica de Salvador, Estado da Bahia, Brasil. Ínsula, v. 27, p. 27-37, 1998

NUNES, J. M. C. Taxonomia morfológica: Metodologia de Trabalho. In: Macroalgas, uma introdução à taxonomia. Rio de Janeiro: Technical Books, 2010. Cap. 2, p. 54-70.
NUNES, J. M. C.; SANTOS, A. C. C.; MINERVINO, A. M.; BRITO, K. S. Algas marinhas bentônicas do Município de Ilhéus, Bahia, Brasil. Acta Bot. Malacitana,v. 24, p. 5-12, 1999.

NUNES, J. M. C.; SANTOS, A. C. C.; LYRA, G. M.; MINERVINO, A. N.; PEDREIRA, E. S. Marine benthic algae from Uruçuca, Bahia, Brazil. Acta Bot. Malacitana, v. 26, p. 181-187, 2001.

NUNES, J. M. C.; PAULA, E. J. Composição e distribuição das Phaeophyta nos recifes da região metropolitana de Salvador, Bahia, Brasil. Iheringia, v. 57, p. 113-130, 2002.

OLIVEIRA, E. C.; BERCHEZ, F. A. Z. Ensayos sobre el cultivo del alga roja Hypnea musciformis (Rhodophyta, Gigartinales) en São Paulo, Brasil. In: Procedimientos del trabajo sobre acuicultura en America Latina. Wageningen: International Foundation for Science; Pudoc, 1987. p. 399-409.

RAO, K. R. Studies on growth cycle and Phycocolloid Content in Hypnea musciformis (Wulf) Lamour. Bot. Mar., v. 13, p. 163-165, 1970.

REIS, R. P.; YONESHIGUE-VALENTIN, Y. Variação espaço-temporal de populações de Hypnea musciformis (Rhodophyta, Gigartinales) na Baía de Sepetiba e Armação dos Búzios, RJ, Brasil. Acta Bot. Bras.,v. 12, p. 465-483, 1998.

REIS, R. P.; YONESHIGUE-VALENTIN, Y. Phenology of Hypnea musciformis (Wulfen) Lamouroux (Rhodophyta, Gigartinales) in three populations from Rio de Janeiro State, Brazil. Bot. Mar.,v. 43, p. 299-304, 2000.

REIS, R. P.; LEAL, M. C. R.; YONESHIGUE-VALENTIN, Y.; BELLUCO, F. Efeito de fatores bióticos no crescimento de Hypnea musciformis (Rhodophyta Gigartinales). Acta Bot. Bras., v. 17, p. 279-286, 2003.

REIS, R. P.; YONESHIGUE-VALENTIN, Y.; SANTOS, C.P. Spatial and temporal variation of Hypnea musciformis carrageenan (Rhodophyta - Gigartinales) from natural beds in Rio de Janeiro State, Brazil. J. Appl. Phycol., v. 20, p.1-8, 2008.

SCHENKMAN, R.P.F. Hypnea musciformis (Rhodophyta): Ecological influence on growth. J. Appl. Phycol., v. 25, p. 192-196, 1989.

WALLNER, M.; LOBO, S.; BOCCANERA, N.; SILVA, E.M. Biomass, carrageenan yield and reproductive state of Hypnea musciformis (Rhodophyta: Gigartinales) under natural and experimental cultivated conditions. Aquacult. Fish. Manage, v. 23, p. 443-451, 1992.

WYNNE, M. J. A checklist of the benthic marine algae of the tropical and subtropical Western Atlantic. Nova Hedwigia Beiheft, 2011.140 p.

ZAR, J. H. Biostatistical analysis. $4^{\text {th }}$ ed. Upper Saddle River, NJ: Prentice-Hall, 1999. 718 p.

(Manuscript received 19 November 2012; revised 12 February 2013; accepted 12 February 2013) 